\title{
Clinical and radiographic changes of carpi, tarsi and interphalangeal joints of beef zebu bulls on semen collection regimen
}

\author{
[Mudanças clínicas e radiográficas das articulações carpo, tarso e interfalangeana de touros de \\ corte zebuínos em regime de colheita de sêmen]
}

\author{
G.A. Motta ${ }^{1}$, A.M. Girardi ${ }^{1 *}$, A.F. Sabes ${ }^{1}$, E.S. Portugal ${ }^{2}$, R.P. Nociti ${ }^{1}$, G.M. Bueno ${ }^{1}$, L.C. Marques ${ }^{1}$ \\ ${ }^{1}$ Universidade Estadual Paulista - UNESP - Jaboticabal, SP \\ ${ }^{2}$ Instituto Federal de Educação Ciência e Tecnologia - IFSULDEMINAS - Muzambinho, MG
}

\begin{abstract}
Osteoarthritis and osteochondrosis are highly correlated to reproductive failure in bulls. This study aimed to evaluate the carpal, tarsal and interphalangeal lesions in beef zebu bulls on semen collection regimen. Twentyone beef cattle bulls, in a total of forty-one animals, were split into three age-based groups: animals from two to four years old (GI), from more than four to eight years old (GII) and above eight years old (GIII). The clinical findings were conformational changes of limbs, synovial effusion, peripheral venous engorgement of joints and prolonged decubitus. The total population showed moderate clinical manifestation and radiographic score. The GIII presented more severe joint lesions. Carpi and tarsi regions had discrete to difuse osteophytosis, subchondral cysts, cartilaginous flaps, bone incongruence and fragmentation, osteitis, and ankylosis. Interphalangeal joints presented osteophytosis, distal phalanx osteitis and enthesophytosis. The digital radiographic examination allowed full identification of articular lesions and their clinical correspondences, besides the positive correlation between age, body weight and radiographic score.
\end{abstract}

Keywords: cattle, infertility, male, overweight, radiology

\section{RESUMO}

Osteoartrite e osteocondrose estão altamente correlacionados à falha reprodutiva em touros. Este estudo teve como objetivo avaliar as lesões do carpo, tarso e interfalangianas em touros zebuínos de corte em regime de coleta de sêmen. Vinte e um bovinos de corte, touros, provenientes de um total de 41 animais, foram divididos em três grupos baseados na idade, sendo eles: animais de dois a quatro anos (GI), de mais de quatro a oito anos (GII) e acima de oito anos de idade (GIII). Os sinais clínicos encontrados foram mudanças de conformação dos membros, derrame sinovial, ingurgitamento venoso periférico das articulações e decúbito prolongado. A população total avaliada apresentou manifestação clínica e escore radiográfico de grau moderado. Os touros mais velhos apresentaram maior gravidade nas lesões articulares. O GIII foi o que apresentou as lesões articulares mais severas. Identificou-se nos carpos osteofitose de discreta a difusa, cistos subcondrais, "flaps" cartilaginosos, fragmentação óssea, perda de congruência óssea, osteite e anquilose; as lesões társicas obedeceram ao mesmo padrão. As articulações interfalangeanas apresentaram somente osteofitose, osteíte nas falanges distais e entesiofitose. $O$ exame radiográfico digital permitiu a identificação completa das lesões articulares e suas correspondências clínicas, além da correlação positiva entre a idade, o peso corporal e o escore radiológico.

Palavras-chave: bovinos, infertilidade, sobrepeso, radiologia, machos

\section{INTRODUCTION}

The degenerative joint disease (DJD) has high correlation with bull reprodutive failure at semen collection centers or in natural breeding programs (Persson et al., 2007). Anatomical conformational defects of hindlimbs, chronic trauma due to semen collection activity and elderly, possibly, contribute to the onset of this disease (Barbosa et al., 2014).

Impotentia coeundi, one of the causes of bull infertility, is the inability to copulate (Noakes et al., 2001) by factors as locomotor system diseases (Noakes et al., 2001). Among these disorders, DJD have chronic and insidious

Recebido em 5 de outubro de 2016

Aceito em 23 de março de 2017

*Autor para correspondência (corresponding author)

E-mail: gabi_marchiori@hotmail.com 
character and can be controlled by nutritional and management practices (Reiland et al., 1978).

Osteochondrosis (OC) and osteoarthritis (OA) are the major DJD (Thompson, 2007). OC is an endochondral ossification disturbance with unknown etiology that can produce free intra articular cartilaginous fragments (Ytrehus et al., 2004), possibly caused by necrosis of blood capillaries of articular cartilage (Ytrehus et al., 2007). It is more common in young animals (Reiland et al., 1978; Marques et al., 1998) because of the relationship with bone development, and often affects animals in high growth rate systems (Reiland et al., 1978; Donabédian et al., 2006). The lateral trochlear ridge of distal femoral epiphysis, the distal intermediate ridge of tibia and the tarsi are the most affected bone regions in bulls (Weisbrode et al., 1982).

Anatomical characteristics related to conformation and body size produce abnormal joint stress and affect the epiphyseal growth plates (Gabel, 1988). High-energy diets stimulate soft tissue growth and fat deposition faster than the bone development, creating lower bearing capacity, instability and offset of force shafts, which culminate in capillary lesions of chondroosseous junctions (Donabédian et al., 2006).

OA comprises overlapping similar conditions that involve components other than the cartilage, as subchondral bone, ligaments, joint capsule, synovial membrane and periarticular muscles (Burr, 2003). Clinical manifestations are more severe when there are joint overload by overweight (Heinola et al., 2013). Fundamentally, the cartilage degenerates into a series of steps until loss of articular surface (Burr, 2003; Thompson, 2007), with osteophytes formation, eburnation, osteosclerosis and ankylosis (Thompson, 2007). The cause can be any condition that causes direct damage to the articular cartilage, create instability or abnormal force direction in its structures, such as joint incongruity in previous $\mathrm{OC}$, overweight and poor conformation of the limbs (Ducharme et al., 1985; Thompson, 2007), affecting primarily adults or elderly animals (Thompson, 2007).

$\mathrm{OC}$ and $\mathrm{OA}$ clinical signs are indistinct and characterized by prolonged decubitus, abnormal posture, difficulty to lie down and get up, progressive lameness, muscle atrophy, reluctance to move, conformational change and increased volume of the joint, synovial effusion and peripheral venous engorgement, being the radiographic examination relevant in diagnostic confirmation and prognosis (Ducharme et al., 1985; Trostle et al., 1997; Nichols and Lardé, 2014).

Digital radiography uses a special detector which, after exposure, provides an image available in computer for immediate analysis and adjustment with better quality, enabling insertion of information and measurements, storage and sharing of images, and quick realization of sequential radiographs (Mcknight, 2004), using smaller amount of radiation (Mcknight, 2004; Kofler et al., 2014) than the conventional method.

Radiography was established as a standard diagnostic method in veterinary medicine, although not a routine practice for ruminants, a situation that is reflected in scientific literature (Kofler et al., 2014). Radiographic evaluation is an important resource for the common bovine locomotor injuries, despite the lack of studies in the area, which justifies the conduction of further research (Lima, 2009).

Thus, the scope of this study was to identify and describe, through digital radiographic examinations of beef zebu bulls, semen donors, injury of carpal, tarsal and interphalangeal joints and their adjacent soft tissues, also evaluating the corresponding clinical signs and the influence of age and body weight on the intensity of the lesions.

\section{MATERIAL AND METHODS}

Twenty-one zebu bulls, from a total of forty one animais, with aptitude for meat production, semen donors at a semen collection center in Brazil, were distributed into three groups of seven animals each, according to age. Goodnatured animals were selected to reduce the risk of accidents during the experiment. Group I (GI) was composed by bulls from two to four years old (one Brahman, three Nellore, two Nellore Mocho and one Tabapuã bull; $2.87 \pm 0.73$ years, $834.43 \pm 74.18 \mathrm{~kg}$ ); group II (GII) by animals from more than four to eight years old (one Brahman, four Nellore, one Nellore Mocho and one Tabapuã bull; $6.58 \pm 1.41$ years, $1102.86 \pm 99.26 \mathrm{~kg}$ ); and group III (GIII) by 
individuals over eight years old (seven Nellore bulls; $10.97 \pm 1.81$ years, $1118.86 \pm 108.24 \mathrm{~kg}$ ). Animals were weighed on a digital scale (Id Beck 2.0, Beckhauser Balanças e Troncos, Paranavaí, Brasil) before the radiographic examination.

During the physical examination, the medical history of the animal and the observation of prolonged recumbency, abnormal posture, difficulty to lie down and get up, muscle atrophy, conformational change of joints (especially of the knee, atlanto-occiptal, tibio-tarsal, intertarsus, carpal and tarsal-metatarsal joints), reluctance to move, joint swelling, synovial effusion and peripheral venous engorgement were considered. For each clinical sign a point was assigned, and bulls were classified into discrete (one to three points), moderate (four to seven points) or severe (eight to ten points) clinical manifestation.

Radiographic examination was performed only once. Carpi and tarsi evaluations were carried out with animals in standing position, contained in a cattle crush. The dorsopalmar (Dpa) and lateromedial (LM) radiographic positions were used for carpi analysis (Bargai et al., 1989). To evaluate the tarsi, radiographic positions were LM and dorsolateral-plantaromedial oblique (DLPIMO) (Bargai et al., 1989). For radiographic analysis of interphalangeal joints, bulls were placed in right lateral decubitus in a hoof-trimming crush (NTB model, NTB Ind. E Com. Prod. To Pec., Brazil) and radiographic positions adopted for thoracic and pelvic digits were palmar dorsal $(\mathrm{PaD})$ and plantar dorsal (PID), respectively.

A direct digital radiography equipment was used (Portable DR system PDX-1417, Poskom Co. LCD, Goyang, South Korea), with the X-ray generator (PXM-40BT, Poskom Co. LCD, Goyang, South Korea) positioned $70 \mathrm{~cm}$ away from the flat panel X-ray detector (Xmaru 1417P, Samsung Eletronics Co. Ltd., Hwaseongsi, South Korea), using $74 \mathrm{kV}$ and $5 \mathrm{mAs}$. Radiographs were processed and analyzed by acquisition software for X-ray images in veterinary medicine (DicomPACS ${ }^{\circ}$ DX-R, OR Technology - Oehm und Rehbein GmbH, Rostock, Germany).

The lesions observed in radiographs were distributed in radiographic scores, numbered from one to four, according to the following criteria: discrete osteophytosis, regular alignment of bones and unaffected periarticular soft tissues. Discrete osteophytosis, presence of subchondral cysts and/or cartilaginous flaps, regular alignment of the periarticular bone and unaffected soft tissue.

Diffuse osteophytosis, presence of subchondral cysts, cartilaginous flaps, periostitis, osteitis, enthesophytosis, ankylosis and/or bone fragments, irregular alignment of bones and unaffected periarticular soft tissues. Diffuse osteophytosis, presence of subchondral cysts, cartilaginous flaps, periostitis, osteitis, enthesophytosis, ankylosis and/or bone fragments, irregular alignment of bones and affected periarticular soft tissues (thickened or radiopaque).

Data analysis was performed using the statistical software package SAS 9.1 (SAS Institute Inc., Cary, North Carolina, USA). Kruskal-Wallis test and subsequently Dunn's multiple comparison test were used when there was a significant difference between medians (non-parametric analysis). The correlation between the variables (age, clinical score, radiographic score, body weight) was made by Spearman's correlation test. The statistical significance was set at $\mathrm{P} \leq 0.05$.

This study was approved by Ethics Commission in Use of Animals of the School of Agrarian and Veterinary Sciences, São Paulo State University, Protocol n ${ }^{\circ} 17100 / 13$.

\section{RESULTS AND DISCUSSION}

Individually, clinical score ranged from zero to five, with average clinical manifestation being $2.57 \pm 1.40$ for GI (discrete), $3.14 \pm 1.35$ for GII (moderate) and 3.86 \pm 1.07 for GIII (moderate). Considering all animals, the clinical manifestation was moderate $(3.19 \pm 1.33)$. There was no difference between groups $(\mathrm{P}>0.05)$.

The frequencies of each clinical sign, by group and by joint, are arranged in Tables 1 and 2, respectively. The main clinical manifestations in periarticular soft tissues are illustrated in Figure 1. 
Table 1. Distribution (\%) of clinical signs observed in beef zebu bulls, semen donors, within each age group (two to four years - GI; more than four to eight years - GII; above eight years - GIII)

\begin{tabular}{lccc}
\multicolumn{1}{c}{ Clinical sign } & GI (7) & GII (7) & GIII (7) \\
\hline Conformational change & 85.71 & 71.43 & 85.71 \\
Joint swelling & 14.29 & 28.57 & 42.86 \\
Peripheral venous engorgement & 85.71 & 0 & 71.43 \\
Synovial effusion & 57.14 & 71.43 & 100 \\
Prolonged recumbency & 14.29 & 42.86 & 85.71 \\
\hline
\end{tabular}

Analyzed sample size between parentheses.

Table 2. Distribution (\%) of clinical signs observed in carpi, tarsi and interphalangeal (thoracic = hands, pelvic $=$ feet) joints of beef zebu bulls, semen donors, within each age group (two to four years - GI; more than four to eight years - GII; above eight years - GIII)

\begin{tabular}{lcccccccc}
\hline \multicolumn{1}{c}{ Clinical sign } & GI (7) & & & & & \\
\hline & Carpi & Tarsi & Carpi & Tarsi & Carpi & Tarsi & Hands & Feet \\
Conformational change & 28.57 & 85.71 & 57.14 & 71.43 & 42.86 & 85.71 & 42.86 & 71.43 \\
Joint swelling & 14.29 & 14.29 & 28.57 & 14.29 & 28.57 & 42.86 & 0.00 & 0.00 \\
Peripheral venous engorgement & 71.43 & 85.71 & 0.00 & 0.00 & 57.14 & 71.43 & 0.00 & 0.00 \\
Synovial effusion & 14.29 & 57.14 & 14.29 & 71.43 & 42.86 & 100.00 & 0.00 & 0.00 \\
\hline
\end{tabular}

Analyzed sample size between parentheses. GI and GII did not showed clinical alterations in hands and feet.
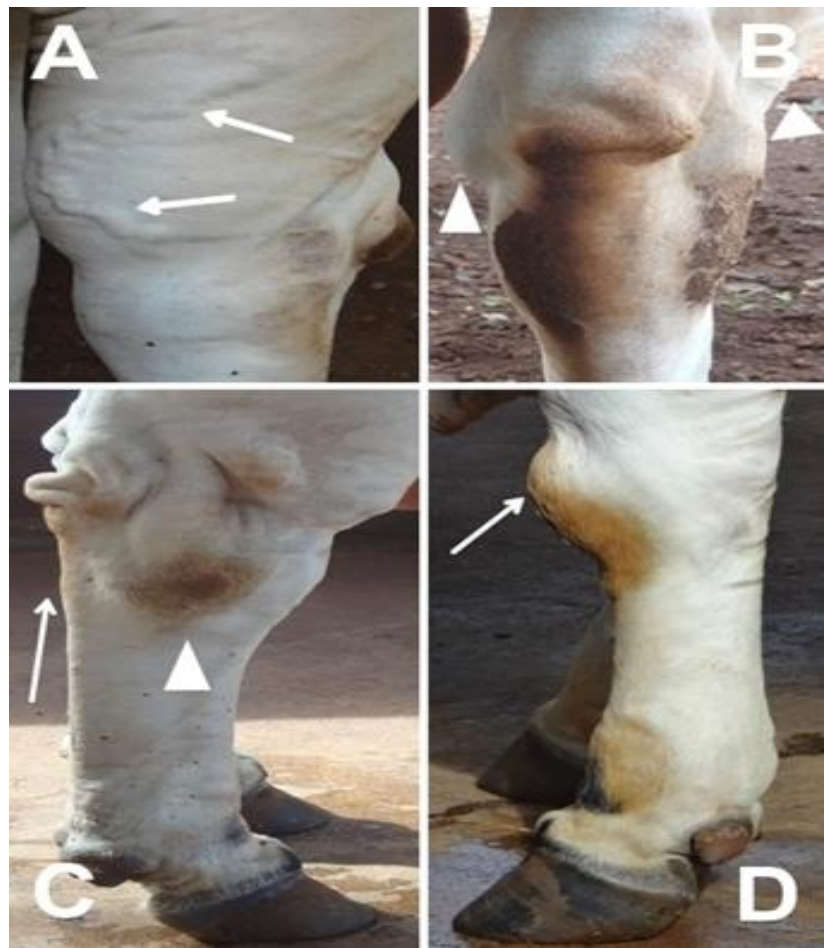

Figure 1. Clinical signs of degenerative joint disease in Nellore bulls. A) Three years old, peripheral venous engorgement at tarsal region (arrows). B) Five years old, bilateral synovial effusion at tarsal region (arrowheads). C) Nine years old, tarsal conformational defect (straight hock) and skin wrinkling in calcaneal region (arrow), hard consistency swelling joint (arrowhead). D) Nine years old, increased volume of periarticular soft tissues - precarpal bursitis (arrow).

Radiographic scores ranged from one to four, with total mean indicating moderate intensity changes. GIII had higher mean $(\mathrm{P} \leq 0.05)$ than GI (Table 3). Radiographic scores of each joint by age group are in Table 4. Percentages of radiographic changes observed in each joint, by age group, are in Table 5. 
Table 3. Distribution (\%), mean and standard deviation (SD) of radiographic score (RS) of beef zebu bulls, semen donors, within each age group (two to four years - GI; more than four to eight years - GII; above eight years - GIII) and of all animals (total)

\begin{tabular}{cccccc}
\hline Group & RS 1 & RS 2 & RS 3 & RS 4 & Mean \pm SD of RS \\
\hline GI (7) & $28.57 \%$ & $57.14 \%$ & $14.29 \%$ & $0 \%$ & $1.86 \pm 0.69 *$ \\
GII (7) & $0 \%$ & $57.14 \%$ & $42.86 \%$ & $0 \%$ & $2.43 \pm 0.53$ \\
GIII (7) & $0 \%$ & $28.57 \%$ & $28.57 \%$ & $42.86 \%$ & $3.14 \pm 0.90 *$ \\
Total (21) & $9.52 \%$ & $47.62 \%$ & $28.57 \%$ & $14.29 \%$ & $2.48 \pm 0.87$ \\
\hline
\end{tabular}

Analyzed sample size between parentheses. Means followed by asterisks in columns differ significantly $(* \mathrm{P} \leq 0.05)$.

Table 4. Mean and standard deviation (SD) of radiographic score (RS) in carpi, tarsi and interphalangeal (thoracic $=$ hands, pelvic $=$ feet) joints of beef zebu bulls, semen donors, within each age group (two to four years - GI; more than four to eight years - GII; above eight years - GIII) and of all animals (total)

\begin{tabular}{ccccc}
\hline Group & Carpi & Tarsi & Hands & Feet \\
\hline GI (7) & $1.57 \pm 0.53$ & $1.86 \pm 0.69$ & $1.29 \pm 0.49$ & $1.0 \pm 0.00$ \\
GII (7) & $2.14 \pm 0.69$ & $2.43 \pm 0.53$ & $2.00 \pm 0.58$ & $1.57 \pm 0.53$ \\
GIII (7) & $2.86 \pm 0.90$ & $3.14 \pm 0.90$ & $2.71 \pm 0.76$ & $2.57 \pm 0.79$ \\
Total (21) & $2.19 \pm 0.87$ & $2.48 \pm 0.87$ & $2.00 \pm 0.84$ & $1.71 \pm 0.85$ \\
\hline
\end{tabular}

Analyzed sample size between parentheses.

Table 5. Distribution (\%) of radiographic findings observed in carpi, tarsi and interphalangeal (thoracic $=$ hands, pelvic $=$ feet) joints of beef zebu bulls, semen donors, within each age group (two to four years GI; more than four to eight years - GII; above eight years - GIII)

\begin{tabular}{|c|c|c|c|c|}
\hline Joint & Radiographic finding & GI (7) & GII (7) & GIII (7) \\
\hline \multirow[t]{8}{*}{ Carpi } & Osteophytosis & 100.00 & 85.71 & 100.00 \\
\hline & Exostosis & 71.43 & 100.00 & 100.00 \\
\hline & Subchondral cysts & 100.00 & 71.43 & 100.00 \\
\hline & Ankylosis & 28.57 & 42.86 & 57.14 \\
\hline & Cartilage degeneration & 0.00 & 0.00 & 42.86 \\
\hline & Periostitis & 0.00 & 0.00 & 28.57 \\
\hline & Bone fissure & 14.29 & 0.00 & 0.00 \\
\hline & Cartilage erosions & 14.29 & 0.00 & 0.00 \\
\hline \multirow[t]{6}{*}{ Hands } & Enthesophytosis & 57.14 & 57.14 & 28.57 \\
\hline & Osteophytosis & 0.00 & 57.14 & 57.14 \\
\hline & Bone fragments & 0.00 & 28.57 & 28.57 \\
\hline & Osteitis & 0.00 & 14.29 & 28.57 \\
\hline & Cartilage erosions & 14.29 & 0.00 & 14.29 \\
\hline & Cartilage degeneration & 0.00 & 14.29 & 0.00 \\
\hline \multirow[t]{10}{*}{ Tarsi } & Osteophytosis & 42.86 & 42.86 & 71.43 \\
\hline & Subchondral cysts & 42.86 & 28.57 & 14.29 \\
\hline & Ankylosis & 0.00 & 14.29 & 57.14 \\
\hline & Exostosis & 14.29 & 28.57 & 28.57 \\
\hline & Irregular alignment of bones & 0.00 & 0.00 & 42.86 \\
\hline & Cartilaginous flaps & 28.57 & 0.00 & 0.00 \\
\hline & Articular compression & 0.00 & 0.00 & 14.29 \\
\hline & Bone fissure & 0.00 & 14.29 & 0.00 \\
\hline & Cartilage erosions & 0.00 & 0.00 & 14.29 \\
\hline & Osteitis & 0.00 & 0.00 & 14.29 \\
\hline \multirow[t]{4}{*}{ Feet } & Enthesophytosis & 42.86 & 85.71 & 71.43 \\
\hline & Osteophytosis & 0.00 & 28.57 & 71.43 \\
\hline & Bone fragments & 0.00 & 14.29 & 14.29 \\
\hline & Bone fractures & 0.00 & 14.29 & 0.00 \\
\hline
\end{tabular}

Analyzed sample size between parentheses. 
The main changes in radiographic pattern of carpi, tarsi and interphalangeal joints are exposed in Figures 2, 3 and 4, respectively.

There was positive correlation between radiographic score and age $(\mathrm{R}=0.62 ; \mathrm{P}=0.0028)$, radiographic score and body weight $(\mathrm{R}=0.56$; $\mathrm{P}=0.0082)$, and between age and body weight $(\mathrm{R}=0.70 ; \mathrm{P}=0.0004)$. The correlation between clinical and radiographic scores was not significant $(\mathrm{R}=0.15 ; \mathrm{P}=0.5277)$.

$\mathrm{X}$-ray examinations were not frequent in buiatrics by the laborious execution and high cost of conventional radiography, irrelevant factors compared to economic losses caused by lameness, loss of milk production and disposal of animals (Bargai et al., 1989; Persson et al., 2007; Kofler et al., 2014;). However, the advent of digital radiography, with smaller equipment and instantaneous imaging, is making this assessment widespread in ruminants as in hippiatrics (Solano, 2004).
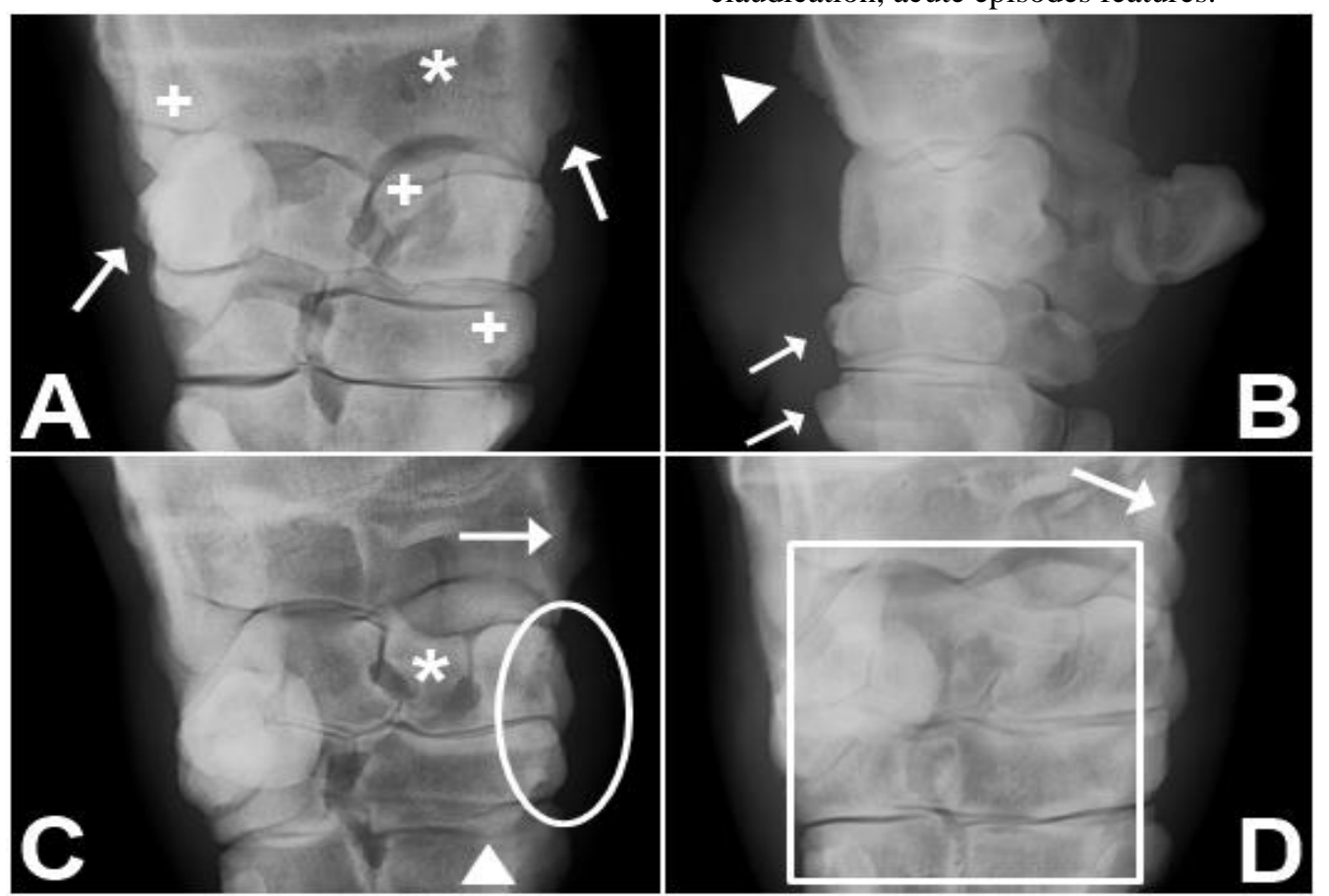

Figure 2. Radiographic findings in carpi of Nellore bulls. A) 12 years old, dorsopalmar projection (DPa), right carpus (RC); osteophytes (arrows), bone fragments (crosses), and subchondral cysts (asterisk). B) 13 years old, lateromedial projection (LM), left carpus; proliferative bone reaction - severe osteophytosis (arrows) and severe periostitis (arrowhead). C) Eight years old, DPa, RC; intense osteophytosis (arrow), cartilaginous flap (arrowhead), subchondral cysts (asterisk) and osteitis (ellipse). D) 12 years old, DPa, $\mathrm{RC}$; ankylosis (rectangle) and intense osteophytes (arrow).
The presented clinical signs corroborate those described for adult cattle (Ducharme et al., 1985; Trostle et al., 1997; Persson et al., 2007; Nichols and Lardé, 2014). The joint conformational change was common in all groups, possibly an early clinical sign of OC, prior to OA. Likewise, synovial effusion may be present in episodes of acute OC and chronic OA. The frequency of prolonged decubitus amounted with aging, possibly, because higher body weight and worsening DJD decrease the support capacity of limbs in standing position. Peripheral venous engorgement signals periarticular inflammation composition (Innes et al., 2013) and is present in GI and GIII groups. The similarity of clinical signs between groups corroborates Nichols and Lardé (2014) for clinical indistinction between $\mathrm{OA}$ and $\mathrm{OC}$ and the validity of radiography for differential diagnosis and prognosis. There were different degrees of OC and OA detectable only in radiographs, but not on physical examination, by absence of regional swelling or severe claudication, acute episodes features. that can disrupt the synovium cellularity and

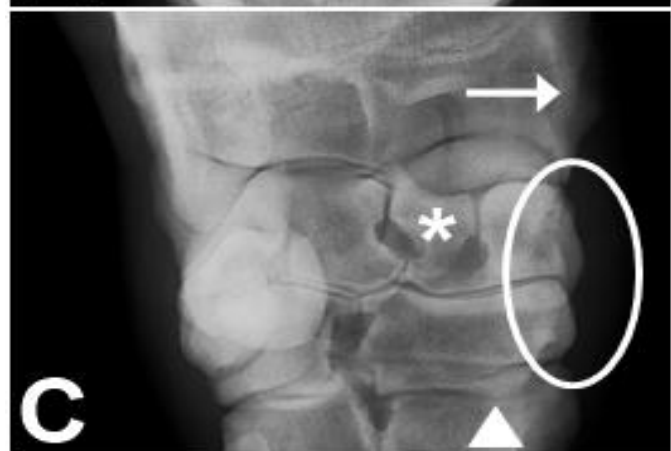



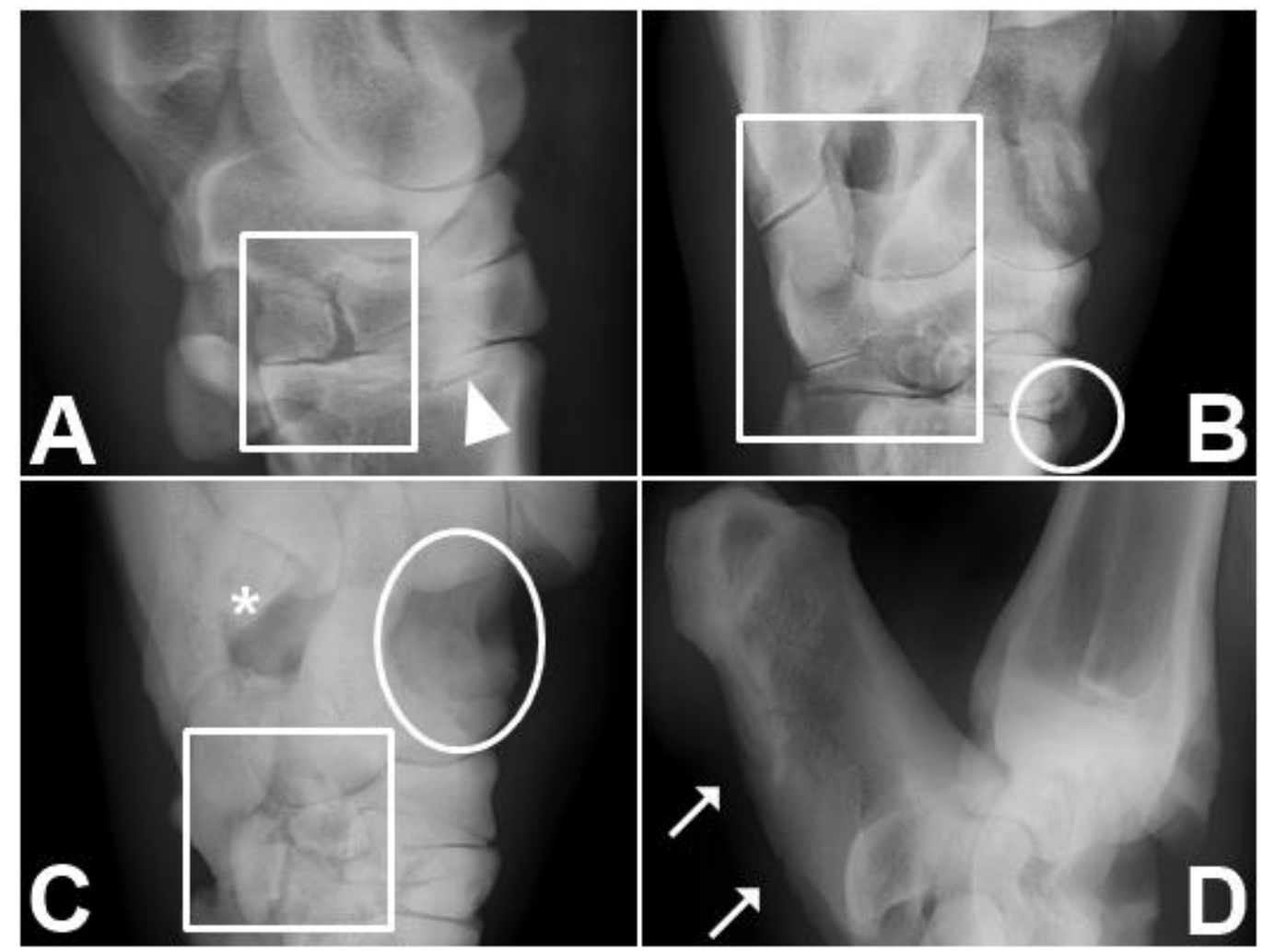

Figure 3. Radiographic findings in tarsi of Zebu bulls. A) Nellore, two years old, lateromedial projection (LM), left tarsus (LT); cartilaginous flap (arrowhead) and bone incongruence (rectangle). B) Tabapuã, eight years old, dorsolateral-plantaromedial oblique (DLPIMO), right tarsus (RT); osteitis (circle) and ankylosis (rectangle). C) Nellore, 12 years old, DLPIMO, RT; ankylosis (rectangle), subchondral cyst in olecranon fossa (asterisk) and cartilage degeneration in talus trochlea (ellipse). D) Nellore, 13 years old, LM, RT; bone reaction in calcaneus plantar surface - periostitis and severe osteophytosis (arrows).
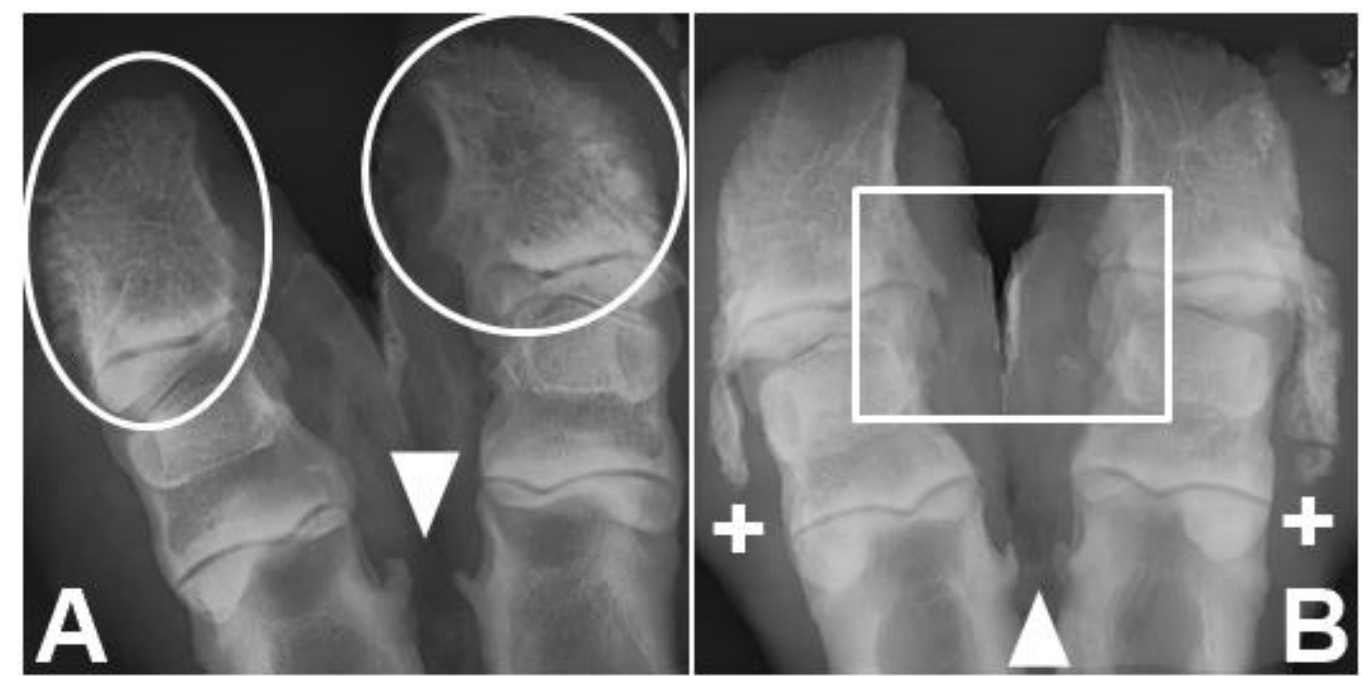

Figure 4. Radiographic findings in interphalangeal joints of Zebu bulls. A) Tabapuã, seven years old, palmar dorsal projection $(\mathrm{PaD})$, right hand; diffuse osteitis at distal phalanges (ellipses) and osteophytes at proximal phalanges (PP) (arrowhead). B) Nellore, 13 years old, PaD, left hand; severe osteitis at middle phalanges (rectangle), severe osteophytosis at PP (arrowhead) and enthesophytosis (crosses). 
Angular deviation of bones, indicative of instability by ligament rupture; joint space narrowing by cartilage destruction; and articular margin irregularities with bone neoformation by chronic instability are indicative of OA. Thickened or sclerotic subchondral bone regions, suggestive of joint stress and cartilage degeneration, indicate OC (Kofler et al., 2014). The DJD findings were similar to those of Lima (2009) and Barbosa et al. (2014) in cattle.

The carpi of the youngest bulls showed subchondral cysts, discrete osteophytosis and cartilaginous flaps, differing from foals, which had larger subchondral cysts and fisites (Denoix et al., 2013), possibly because the latter were youger, had more active behavior and more fragile skeleton than the cattle studied. All age groups showed discrete and diffuse osteophytosis, subchondral cysts, bone incongruence and cartilaginous flaps. The oldest bulls had aggravated injuries, with carpal spontaneous fractures, ankylosis and osteitis, characterizing OA (Kofler et al., 2014). Bone reaction on dorsal side of carpal bones and contiguous soft tissue in all groups is due to chronic local trauma due to lying down and standing up, when the animal supports its weight on this small area, which has no load-damping mechanisms. Therefore, high body weights and aging exacerbate these injuries.

The tarsus of bulls over eight years old showed more severe changes, with cartilage erosions in large joint surfaces, as in the trochlea of talus, cysts in olecranon fossa and ankylosis of tarsal bones. The youngest bulls had few alterations in tarsal radiographic pattern. Bone and periosteal reactions in the calcaneus plantar surface were consequence of effort during semen collection, in which the bull repeatedly mounts the dummy cow. The tarsal lesions were similar to those found in necropsies of semen donor bulls from two to nine years old (Persson et al., 2007) and one-year-old bulls from a reproducers selection program (Dutra et al., 1999). Possibly these findings in younger animals are related to the high growth rate (Dutra et al., 1999).

DJD signals are common in interphalangeal joints of bovines over seven years old (Bargai et al., 1989), and this study certifies that older animals showed high frequency of narrowed joint spaces, periarticular exostosis, enthesophytosis, marginal osteitis and periostitis in the distal phalanges. The enthesophytosis is considered a natural consequence of aging (Weaver, 1969). Among the interphalangeal joints, the distal is the most affected, mainly due to penetrating injuries and infections through the hoof, with osteitis prevalent at the distal phalanx (Berry, 2001). However, the high occurrence of osteitis at the distal phalanx was related to overloading of digits in this study, as described by Barnabé (2005). As observed in all groups, such radiographic findings have not necessarily clinical implication in cattle (Scudeller et al., 2002). The exostosis described in the phalanges resemble previous radiographic findings in cattle (El-Shafaey et al., 2013).

Age and excessive weight aggravate injuries in the three studied joints. Therefore, the nutritional parameters adopted for these animals, which induce weight gain beyond the physiological margins in the sedentary conditions in which they are kept, should be reviewed. Some researchers confirm the influence of aging at the onset of DJD, but also described findings suggestive of the disease in young cattle (Marques et al., 1998; Persson et al., 2007; Barbosa et al., 2014; Nichols and Lardé, 2014). The presence of more severe radiographic changes in older cattle is understandable because $\mathrm{OA}$ is a pathological process characteristic of senile animals (Thompson, 2007), which also exhibit heavier body weights.

Over the years as semen donor are observed, concomitantly with the increase of DJD, changes in the pattern of bull jump for semen collection. Bulls with DJD in a breeding center produced low-quality semen and lost the jump ability for semen collection (Barbosa et al., 2014). Occasionally, bulls in artificial insemination centers, when there is high demand for their products, have their productive lifes impaired by diffuse involvement of the joints, damage that would be ameliorated if breeding program data are more valuable to the bull evaluation than the commercial aesthetic pattern of obesity. As advocated for pigs, breeding programs should include the conformational evaluation of limbs and biomechanics of movement, associated with signs of DJD, valuing longevity and prevention of lameness (Stavrakakis et al., 2014), considering the extent that the product of bulls can reach and its effect on livestock, especially 
in extensive systems that rely on great mobility of animals.

The present results suggest that the radiographic evaluation of joints of the limbs are a valuable tool in the marketing of bulls for natural breeding programs or for admission as semen donors in artificial insemination centers. It highlights the importance of maintaining the healthy body weight of these animals, in order to preserve the young bulls through normal growth, and to improve the quality and length of productive life of adult and elderly bulls due to relief joint.

\section{CONCLUSION}

Physical and digital radiographic examinations were effective in identifying diseases that involve carpi, tarsi and interphalangeal joints of zebu bulls in semen collection system. Their age group and body weight were highly correlated with the severity of radiographic injuries. The body weight of semen donor bulls should be at physiological levels to preserve their joint health and, thus, their productive capacity.

\section{REFERENCES}

BARBOSA, J.D.; LIMA, D.H.S.; BELO-REIS, A.S. et al. Degenerative joint disease in cattle and buffaloes in the Amazon region: a retrospective study. Pesqui. Vet. Bras., v.34, p.845-850, 2014.

BARGAI, U.; PHARR, J.W.; MORGAN, J.P. Bovine radiology. Ames: Iowa State University, 1989. p.198.

BARNABÉ, P.A. Alterações radiográficas nos dedos de bovinos claudicantes. 2005. 50f. Tese (Doutorado em Cirurgia Veterinária). Faculdade de Ciências Agrárias e Veterinárias, Universidade Estadual Paulista "Júlio de Mesquita Filho", Jaboticabal, SP.

BERRY, S.L. Diseases of the digital soft tissues. Vet. Clin. N. Am. Small, v.17, p.129-142, 2001.

BURR, D.B. Subchondral bone in the pathogenesis of osteoarthritis. Mechanical aspects. In: BRANDT, K.D.; DOHERTY, M.; LOHMANDER, L.S. Osteoarthitis. Oxford: Oxford University Press, 2003, p.125-133.
DENOIX, J.M.; JACQUET, S.; LEPEULE, J. et al. Radiographic findings of juvenile osteochondral conditions detected in 392 foal using a field radiographic protocol. Vet. J., v.197, p.44-51, 2013.

DONABÉDIAN, M.; FLEURANCE, G.; PERONA, G. et al. Effect of fast vs moderate growth rate related to nutrient intake on developmental orthopaedic disease in the horse. Anim. Res., v.55, p.471-486, 2006.

DUCHARME, N.G.; STANTON, M.E.; DUCHARME, G.R. Stifle lameness in cattle at two veterinary teaching hospitals (42 cases). Can. Vet. J., v.26, p.212-217, 1985.

DUTRA, F.; CARLSTEN, J.; EKMAN, S. Hind limb skeletal lesions in 12-month-old bulls of beef breeds. J. Veterinarmed. A, v.46, p.489-508, 1999.

EL-SHAFAEY, E.S.A.A.; AOKI, T.; ISHII, M. et al. Pilot study of bovine interdigital cassetteless computed radiography. J. Vet. Med. Sci., v.75, p.1503-1506, 2013.

GABEL, A.A. Metabolic bone disease: problems of terminology. Equine Vet. J., v.20, p.4-6, 1988.

HEINOLA, T.; GRAUW, J.C.; VIRKKI, L. et al. Bovine chronic osteoarthritis causes minimal change in synovial fluid. J. Comp. Pathol., v.148, p.335-344, 2013.

INNES, J.F.; GORDON, C.; VAUGHANTHOMAS, A. et al. Evaluation of cartilage, synovium and adipose tissue as cellular sources for osteochondral repair. Vet. J., v.197, p.619624, 2013.

KOFLER, J.; GEISSBÜHLER, U.; STEINER, A. Diagnostic imaging in bovine orthopedics. Vet. Clin. N. Am. Food Anim. Pract., v.30, p.1153, 2014.

LIMA, I.R. Estudo clínico e radiográfico das extremidades distais dos membros locomotores de bovinos machos de corte. 2009. 53f. Dissertação (Mestrado em Ciência Animal) Escola de Veterinária da Universidade Federal de Goiás. Goiânia, GO.

MARQUES, L.C.; ALESSI, A.C.; CANOLA, J.C. Osteocondrose em bovinos confinados. Arq. Bras. Med. Vet. Zootec., v.50, p.95-98, 1998.

MCKNIGHT, A.L. Digital radiography in equine practice. Clin. Tech. Equine, v.3, p.352-360, 2004. 
NICHOLS, S.; LARDÈ, H. Noninfectious joint disease in cattle. Vet. Clin. N. Am. Food Anim. Pract., v.30, p.205-223, 2014.

NOAKES, D.E.; PARKINSON, T.J.; ENGLAND, G.C.W. Arthur's veterinary reproduction and obstetrics. London: Saunders, 2001. 480p.

PERSSON, Y.; SÖDERQUIST, L.; EKMAN, S. Joint disorder; a contributory cause to reproductive failure in beef bull? Acta Vet. Scand., v.49, p.31-38, 2007.

REILAND, S.; STROMBERG, B.; OLSSON, S.E. et al. Osteochondrosis in growing bulls. Pathology, frequency and severity on different feedings. Acta Radiol. Suppl., v.358, p.179-196, 1978.

SCUDELLER, P.S.O.; MUNIZ, L.M.R.; CROCCI, A.J. Ocurrencia de alteraciones radiográficas podales sin sintomas clínicos en hembras bovinas de las raças Nelore y Holstein Friesian. In: CONGRESSO BRASILEIRO DE MEDICINA VETERINÁRIA, 29., 2002, Gramado. Anais... Porto Alegre: Fábrica de Idéias, 2002.

SOLANO, M. Equine radiography: portable Xray generators, film-screen technology, and tabletop automatic film processors. Clin. Tech. Equine Pract., v.3, p.328-340, 2004.
STAVRASKAKIS, S.; GUY, J.H.; WARLOW, O.M.E. et al. Walking kinematics of growing pigs associated with differences in musculoskeletal conformation, subjective gait score and osteochondrosis. Livest. Sci., v.165, p.104-113, 2014.

THOMPSON, K. Bones and joints. In: MAXIE, M.G. Jubb, Kennedy and Palmer's - pathology of domestic animals. 5.ed. St. Louis: Saunders Elsevier, 2007. cap.1, p.1-184.

TROSTLE, S.S.; NICOLL, R.G.; FORREST, L.J. et al. Clinical and radiographic findings, treatment and outcome in cattle with osteochondrosis: 29 cases (1986-1996). J. Am. Vet. Med. Assoc., v.211, p.1566-1570, 1997.

WEAVER, A.D. Radiology of the bovine foot. Br. Vet. J., v.125, p.573-579, 1969.

WEISBRODE, S.E.; MONKE, D.R.; DODARO, S.T. et al. Osteochondrosis, degenerative joint disease and vertebral osteophytes in middle aged bulls. J. Am. Vet. Med. Assoc., v.7, p.700-705, 1982.

YTREHUS, B.; CARLSON, C.S.; EKMAN, S. Etiology and pathogenesis of osteochondrosis. Vet. Pathol., v.44, p.429-448, 2007.

YTREHUS, B.; HAGA, H.; MELLUM, C. et al. Experimental ischemia of porcine growth cartilage produces lesions of osteochondrosis. $J$. Orthop. Res., v.22, p.1201-1209, 2004. 